\title{
Pengembangan UMKM unggulan Gambo Muba produk lokal guna menopang perekonomian rakyat akibat COVID-19
}

\author{
Lesi Hertati ${ }^{*}$; Irlan Feri²; Lilis Puspitawati3; Rilla Gantino ${ }^{4}$, Meifida Ilyas ${ }^{5}$ \\ $\left.{ }^{1 *}\right), 2$ Lecture Faculty of Economics and Accounting, STIE Rahmaniyah Muba-Indonesia \\ ${ }^{3}$ Lecturer, Faculty of Economics and Accounting University Komputer Bandung-Indonesia \\ ${ }^{4}$ Lecturer, Faculty of Economics and Accounting University Esa Unggul Jakarta-Indonesia \\ ${ }^{5}$ Lecturer, Faculty of Economics and Accounting University Satya Negara-Indonesia
}

Email: hertatilesi@yahoo.co.id

\begin{abstract}
Gambo Muba is a product of micro, small, and medium enterprises originating from the Musi Banyuasin community, which comes from Gambir sap waste which is used to give jumputan fabric colors. The way of making it is indeed not easy, the craftsman must know the fashion traditions of the toy in order to achieve good results. The motifs are tailored to market needs and according to buyers' interests, including current trends. For the manufacture itself, awareness and knowledge are needed to preserve the Gambo Muba jumputan culture. Especially the local craftsman level because this craft is done manually or by hand. Jumputan's typical Gambo fabric, which is a type of jumputan that is done with a tie-dye technique to create interesting color gradations. Not written in a wax like batik in general, the cloth will be tied and then dyed in color. The gambo Muba UMKM survey was conducted on micro, small, and medium enterprises in Musi Banyuasin Regency, South Sumatra, Indonesia. The results of community service that we surveyed were people who made Gambo Muba's micro, small, and medium-sized business products during the Covid-19 season very much to help people's household lives during the Covid-19 season where all residents on earth had to lockdown, to reduce the spread of the Covid-19 virus.

Kata kunci: COVID-19, Micro, Small And Medium Enterprises Gambo Muba, Local Muba Micro, Small And Medium Enterprises

Abstrak: Gambo Muba adalah produk usaha mikro kecil menengah asli masyarakat Musi Banyuasin, yang berasal dari limbah getah Gambir dimanfaatkan untuk memberi corak warna kain jumputan. Cara pembuatanya memang tak mudah, pengrajin harus tahu akan tradisi mode perkainan agar dapat mewujudkan hasil yang baik. Motifnya disesuaikan dengan kebutuhan pasaran dan sesuai minat pembeli, termasuk trend kekinian. Untuk pembuatannya sendiri, diperlukan kesadaran dan ilmu pengetahuan guna melestarikan budaya jumputan Gambo Muba. Terutama tingkat pengrajin lokal karena kerajinan ini dikerjakan secara manual alias pakai tangan. Kain Gambo khas Jumputan, yaitu jenis jumputan yang dikerjakan dengan teknik ikat celup untuk menciptakan gradasi warna yang menarik. Tidak ditulis dengan malam seperti batik pada umumnya, kain akan diikat lalu dicelupkan ke dalam warna. Survey UMKM gambo Muba ini dilakukan pada usaha mikro kecil menengah di Kabupaten Musi Banyuasin Sumatera Selatan-Indonesia. Hasil Pengabdian Pada Masyarakat yang kami survey adalah masyarakat yang membuat produk usaha mikro kecil menengah Gambo Muba pada musim Covid-19 sangat membantu kehidupan rumah tangga masyarakat pada musim Covid-19 dimana seluruh penduduk di muka bumi harus lockdown, guna mengurangi penyebaran virus Covid-19.
\end{abstract}

Keywords: COVID-19, UMKM Gambo Muba, UMKM Kearifan Lokal Muba 


\section{Pendahuluan}

Usaha mikro kecil menengah adalah kelompok usaha rumahan yang ada dikabupaten Musi Banyuasin sebagai roda penggerak perekonomian masyarakat local akibat terjadinya ketidakpastian lingkungan alam yang melanda dunia seperti virus Corona melanda seluruh penghuni dunia. Usaha mikro kecil menengah yang digiatkan masyarakat Muba adalah produk Gambo Muba yang mengangkat produk kearifan lokal dan memberikan kontribusi positif bagi petani Gambir dan pengrajin Gambo Muba. Usaha mikro kecil menengah dengan bahan baku dari getah Gambir yang sangat ramah lingkungan.getah Gambir adalah cara masyarakat local Muba dalam mengelolah warna kain Gambo asli Muba untuk kegiatan UMKM sebagai Inisiator bahan dasar pewarna jumputan Gambo Muba. Produk jumpututan Gambo Muba bahwasanya bahwa produk ini sudah dipasarkan hingga ke mancanegara dengan teknik celup rintang menggunakan tali, untuk menghalangi bagian tertentu di kain agar tidak menyerap warna lain sebelum terbentuk motif. Gambo Muba, menjadi tren mode baru batik jumputan dengan sentuhan modern. Akibat penyebaran virus Corona sehingga banyak usaha mikro kecil menengah yang tergeletak. Terutama teknik penggunaan malam dengan menutup sebagian kain saat proses pewarnaan. Setelah pewarnaan selesai, pengrajin mulai membuat motif dengan keunikan dan arti tertentu.

Dimana-mana usaha mengalami kemacetan bisnis secara mendadak, sehingga untuk bertahan hidup ibu-ibu di kabupaten Musi Banyuasin menggelutin usaha mikro kecil menengah yaitu Gambo Muba sebagai produk rumahan, yang mereka lakukan untuk menopang ekonomi keluarga. Produk UMKM rumahan inilah cara masyarakat Muba untuk mencegah penularan virus Corona dari orang ke orang akibat kontak langsung, sehingga setiap orang harus menjaga jarak agar penyebaran virus dapat dikurangi kemudian intruksi pemerintah aktivitas di luar rumah dikurangi agar virus tidak menyebar luas. Gambo Muba termasuk produk modern secara proses pembuatan, tetapi juga modern dari tampilan dan jangkauan pasarnya Brentani \& De. (1993). Jumputan diberi nama Gambo ini karena bahan pewarnaannya berasal dari getah Gambir kalau biasanya ada pakai zat kimia, kali ini dibuat dengan pewarnaan alami seperti gambar dibawah ini proses awal getah gambir:

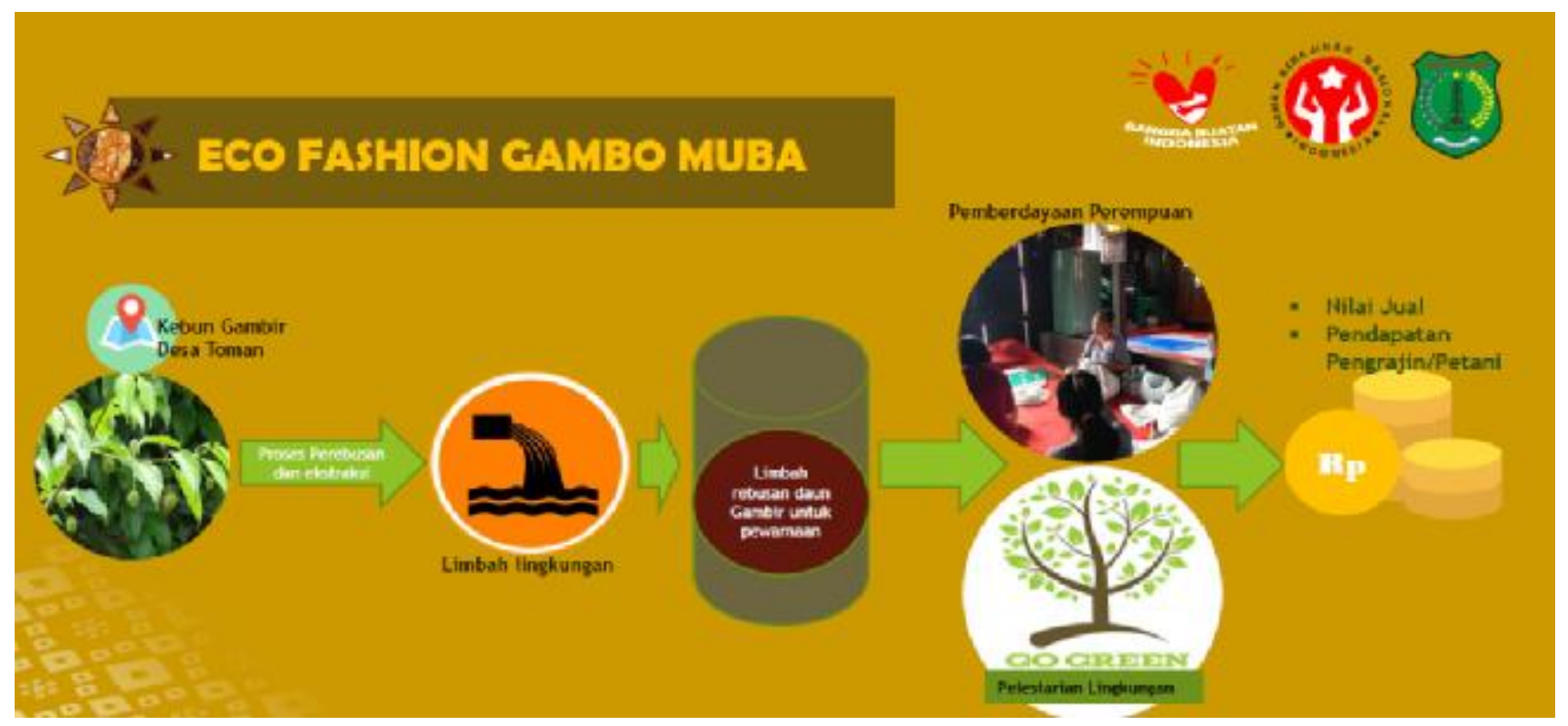

Sumber: Gambar 1 proses awal getah Gambir, 2020

UMKM (usaha mikro kecil dan menengah) Muba berfungsi memberdayakan para penjumput perempuan di desa-desa guna mampu meningkatkan perekonomian masyarakat di tengah Pandemi COVID-19 kerja sama ini juga merambah pada protype desain. Aplikasi Gambo Muba pada produk interior, art decor, furniture dan arsitektur. Sebagaimana kita ketahui Gambo Muba telah memperluas 
pangsa pasar menjadi produk non-fashion yakni menjadi bahan untuk kelengkapan furniture dan interior hotel, bahkan sudah beberapa hotel bintang lima di Jakarta yang memakai Gambo Muba sebagai kebutuhan interior yaitu produk asli daerahnya ke depan dapat terus bersaing. Sehingga dapat menjadi inovasi-inovasi kekinian yang terus berkembang. Sesuatu yang tidak berguna dicoba manfaatkan dengan maksimal supaya memiliki nilai tinggi dan menghasilkan sesuatu yang luar biasa, terutama untuk perkembangan industri tekstil.

Gambo Muba adalah eco fashion yang mampu mengangkat ekonomi petani getah Gambir. Lantaran dikerjakan oleh tangan-tangan terampil para ibu-ibu di desa guna menopang penghasilan keluarga dan meningkatkan perekonomian kesejahteraan keluarga. Peningkatan perekonomian keluarga adalah cara pengembangan dan inovasi Gambo Muba yang mengusung prinsip produksi yang rama lingkungan. Dengan hanya menggunakan bahan-bahan yang ramah lingkungan. Kemudian keberlangsungan dan kelestarian Gambo Muba akan terus menggunakan limbah-limbah. Gambo hanya akan memakai hal-hal yang berbahan dasar alami. Gambo Muba diproduksi guna kesejahteraan masyarakat Musi Banyuasin yaitu keberpihakan pada ekonomi kerakyatan guna menopang ekonomi keluarga. Athanassopoulou, \& Johne, (2003) menyatakan produk Gambo Muba akan terus berkembang dan berinovasi baik di level nasional maupun internasional. Para desaigner dan arsitek dunia bicara, pada dasarnya semua desain akan kembali ke natural, kembali ke budaya kerajinan tangan Muba. Gambo Muba punya tradisi yang kuat dan harus kita kembangkan jangan hanya berhenti di dunia fashion saja (Broadbent,et,all 1996). Tentu wastra ini dapat dimasukan dalam produk interior dan dekoratif. Beberapa contoh yang sudah kita kembangkan, seperti pada kain sofa, sehingga proyek di sebuah hotel bahkan presidensial bisa digunakan.

Pewarna alami getah Gambir ini pada sebuah kayu alami putih polos ternyata pewarna getah Gambo bisa mengubah warna lebih indah. Ketika diaplikasikan pada interior bisa jadi se-modern. Produk Gambo Muba mampu menjadi trend furniture berdaya saing global, seperti terlihat pada gambar berikut ini.

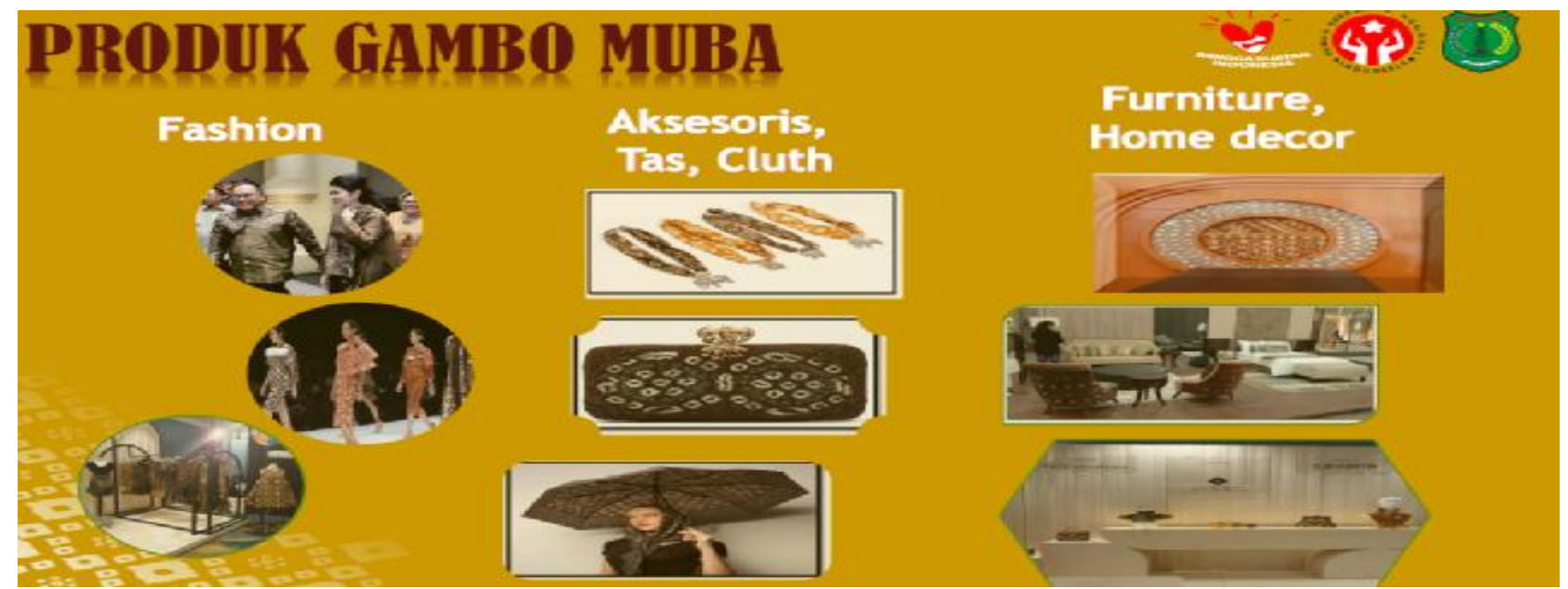

Sumber : gambar 2 adalah produk hasil olahan getah Gambir d Muba, 2020

Gambir Muba adalah salah satu bagian yang sangat penting esensial sekali untuk produk farmasi. Gambir Muba selain sebagai obat Antibiotik alami, Gambir Muba adalah satu-satunya Gambir yang terbaik di Indonesia. Keunggulan Gambo Muba, produk adalah memiliki nilai estetika yang tinggi karena penggunaan bahan pewarnaan alami. Kerajinan asli tangan pemberdayaan masyarakat terutama para ibu-ibu rumah tangga yang dapat meningkatkan pendapatan ekonominya yaitu produk Gambir Muba sangat ramah lingkungan. Pada awalnya jumputan Gambir Muba diusahakan ibu- ibu rumah tangga. Kemudian berkembang pesat dan membentuk UMKM (Usaha Mikro, Kecil, Menengah) dengan ciri khas Gambir Muba adalah komoditi/barang yang ada pada usahanya tidak tetap, atau bisa berganti sewaktu-waktu, kemudian tempat menjalankan usahanya bisa berpindah sewaktu-waktu. 
Fenomena seperti diungkapkan oleh Teten Masduk (2020) selaku Menteri Koperasi dan UMKM menyatakan bahwa 949 pelaku koperasi dan usaha mikro, kecil dan menengah (UMKM) yang terdampak wabah virus corona (Covid-19). Sebanyak 774 koperasi dan UMKM atau setara dengan 68 persen, mengeluh penjualannya menurun akibat dampak wabah virus corona. Penurunkan penjualan dirasakan di DKI Jakarta, Banten, Jawa Barat, Jawa Tengah, Jawa Timur, DIY, Sumatera Utara, Sumatera Barat, Riau, Bengkulu, Bali, Kalimantan Barat, Kalimantan Timur, Sulawesi utara, Sulawesi tengah, Sulawesi Selatan, Sumatera Selatan dan Kalimantan Selatan.

Industri kreatif Gambo Muba adalah pengembangan jenis industri yang saat ini telah dilakukan oleh pemerintah kabupaten Muba. Konsep industri kreatif Gambo Muba bertumpu pada pengembangan ide, kreativitas, keterampilan, serta bakat individu untuk menciptakan kesejahteraan dan lapangan pekerjaan ditengah hebatnya goncangan Covid-19 sehingga ibi-ibu di kabupaten Muba harus bekerja agar bisa bertahan hidup dengan menghasilkan karya tangan lukisan gambo Muba dan mengeksploitasi daya kreasi dan daya cipta individu tersebut (Anshoff, 1972).

Pengembangan industri kreatif Gambo Muba akan memberikan nilai lebih karena menawarkan pembangunan yang berkelanjutan melalui pemanfaatan cadangan sumber daya limbah alam dari getah Gambir yang bukan hanya terbarukan bahkan tak terbatas, yaitu ide, talenta dan kreativitas. Kemudian Archak, et,all (2011) menyatakan bahwa industri kreatif Gambo Muba merupakan kegiatan usaha yang bersumber dari kreativitas, keahlian, dan talenta individu yang berpeluang meningkatkan kesejahteraan dan lapangan kerja yang menciptakan daya tarik yang diminati para pemburu kain jumputan Gambo Muba karena warna secara alamiah yang lembut. Selanjutnya Borch (1947), menyatakan bahwa industri kreatif Gambo Muba adalah industri yang nilai dari produk alamiah yaitu kegiatan yang dihasilkan dengan peralatan tangan tanpa bantuan mesin lebih ditentukan oleh kreativitas penciptanya. Hal yang sama diungkapkan oleh Best, (2013) menyatakan bahwa industri kreatif Gambo Muba memiliki ciri-ciri sebagai berikut: siklus hidup yang singkat, risiko kegagalan yang rendah, dapat menghasilkan margin keuntungan, memiliki keanekaragaman warna dan motip, iklim persaingan bisnis yang tinggi, dan produk yang sulit ditiru pesaing lain disebabkan alam yang berbedah (Bryson \&Eden, 2007).

Bughin.(1996) and Gartner \& Hills (2003) menyatakan bahwa usaha mikro kecil menengah jumputan Gambo Muba belum menerapkan administrasi, bahkan keuangan pribadi dan keuangan usaha masih disatukan. Sumber daya manusia (SDM) di dalamnya belum punya jiwa wirausaha yang mumpuni Biasanya tingkat pendidikan SDM nya masih rendah. UMKM Gambo Muba adalah memanfaatkan waktu luang bagi perempuan Muba dengan tenaga kerja sampingan guna membantu suami menyadap pohon karet di setiap pagi, kemudian pulang dari menyadap karet dan sorenya melakukan penjemputan kemudian hasil karya masyarakat ibu-ibu. Berikut dibawah ini adalah contoh dari hasil kerajinan Gambo Muba seperti terlihat pada gambar 3.

Permasalahan yang terjadi pada Usaha mikro kecil menengah gambo Muba adalah bagaimana meningkatkan kinerja agar dapat tumbuh dan berkembang di tengah situasi persaingan yang dimasa Covid-19 sedang berlasung. Permasalahan selama ini adalah belum adanya suatu standard baku yang menjadi rujukan bagi para perajin sehingga seringkali tidak dapat mengukur pencapaian usaha yang telah dijalankan. Adanya pengukuran dan evaluasi kinerja menyebabkan pelaku industri kecil kerajinan dapat mengetahui kondisi perusahaan yang dipimpinnya dan memiliki parameter yang jelas dan menjalankan bisnis. Kinerja Usaha mikro kecil menengah gambo Muba dalam penelitian ini adalah bagaimana UMKM Gambo Muba bisa diminati masyarakat di seluruh Dunia guna meningkatkan perekonomian rakyat kecil yang dilanda kecemasan akibat terjangan Corona yang belum jelas kapan akan berakhirnya. 


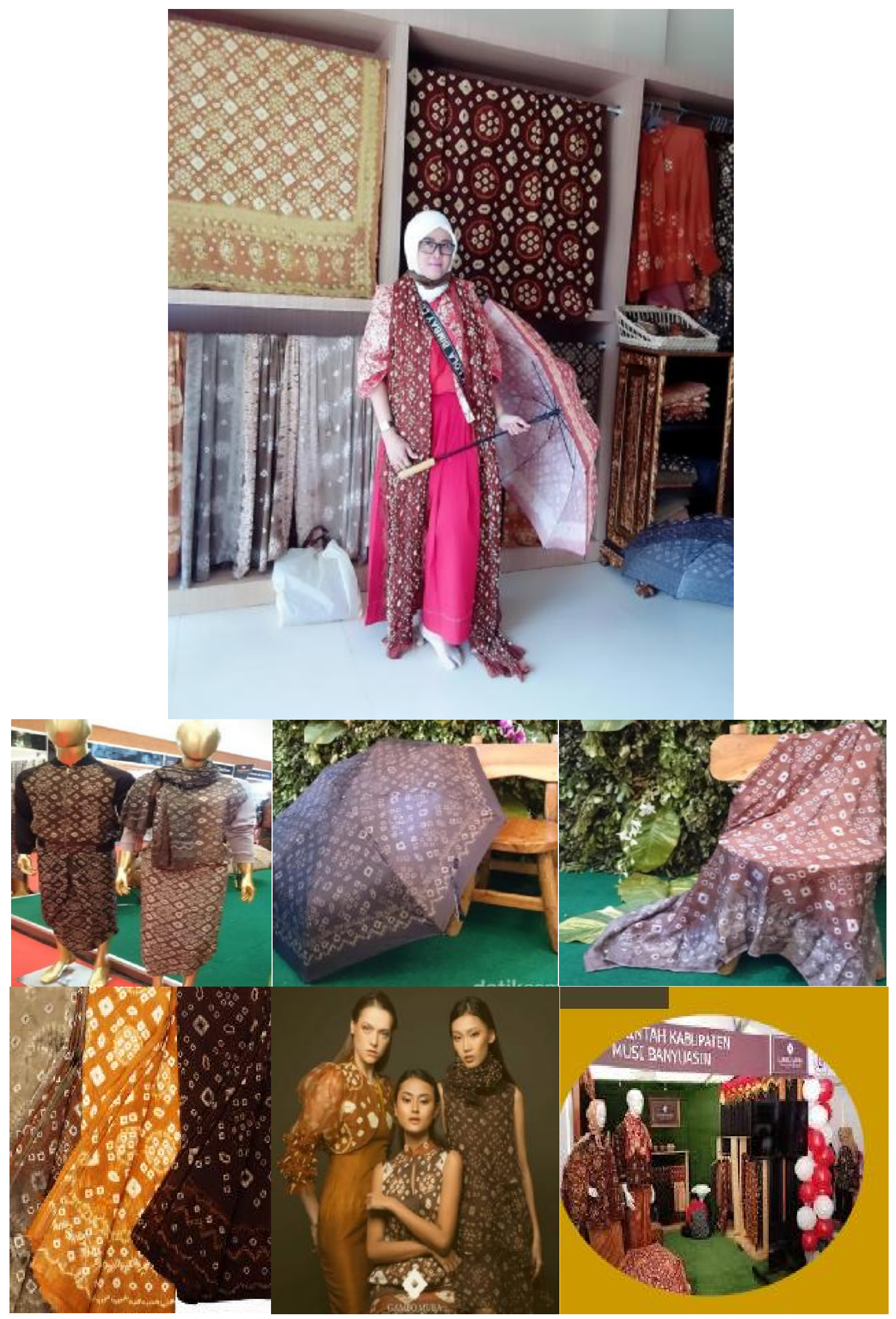

Gambar 3: Hasil UMKM Produk Gambo Muba, 2020 
Permasalahan yang terjadi pada Usaha mikro kecil menengah gambo Muba adalah bagaimana meningkatkan kinerja agar dapat tumbuh dan berkembang di tengah situasi persaingan yang dimasa Covid-19 sedang berlasung. Permasalahan selama ini adalah belum adanya suatu standard baku yang menjadi rujukan bagi para perajin sehingga seringkali tidak dapat mengukur pencapaian usaha yang telah dijalankan. Adanya pengukuran dan evaluasi kinerja menyebabkan pelaku industri kecil kerajinan dapat mengetahui kondisi perusahaan yang dipimpinnya dan memiliki parameter yang jelas dan menjalankan bisnis. Kinerja Usaha mikro kecil menengah gambo Muba dalam penelitian ini adalah bagaimana UMKM Gambo Muba bisa diminati masyarakat di seluruh Dunia guna meningkatkan perekonomian rakyat kecil yang dilanda kecemasan akibat terjangan Corona yang belum jelas kapan akan berakhirnya.

\section{Litelature Review}

Sumber daya manusia yang kreatif adalah salah satu faktor yang penting dalam suatu usaha mikro kecil menengah, di samping faktor lain seperti aktiva dan modal, oleh karena itu sumber daya manusia dan modal harus dikelola dengan baik untuk meningkatkan efektivitas dan efisiensi organisasi, sebagai salah satu fungsi dalam usaha mikro kecil menengah, yang dikenal dengan manajemen sumber daya manusia kreatif.

Mathis \& Jackson (2012:5) manajemen sumber daya manusia (MSDM) dapat diartikan sebagai ilmu dan seni yang mengatur hubungan dan peranan tenaga kerja agar efektif dan efisien dalam penggunaan kemampuan manusia agar dapat mencapai tujuan di setiap usaha. Gartner,et,all (2013) menyatakan bahwa manajemen sumber daya manusia sebagai kebijakan dan latihan untuk memenuhi kebutuhan kreatifitas tangan manusia berbagai aspek-aspek penting didalam mendesign produk yang tepat karena di dalam sumber daya manusia seperti posisi manajemen, pengadaan karyawan atau rekruitmen, penyaringan, pelatihan, kompensasi dan penilaian prestasi kerja karyawan. Adapun alasan manajemen sumber daya manusia digunakan karena mampu mencakup keseluruhan aspek penting yang diteliti kecerdasan design, kompetensi kreativitas, inovasi, serta kinerja perajin industri usaha mikro kecil menengah Gambo Muba.

\section{UMKM Gambo Muba.}

Kerajinan tangan masyarakat Muba adalah kain jumputan yang dikenal dengan UMKM Gambo Muba yaitu kemampuan untuk mengidentifikasi dan memperoleh atau membuat pasar berdasarkan kreatipitas tangan serta kesempatan dan kebutuhan sumber daya (Mei Yane Chung W (2012). Kemudian Kompetensi sumberdaya manusia didalam merakit usaha mikro kecil menengah adalah sebagai karakteristik mendasari generik pengetahuan khusus, motif, sifat-sifat, citra diri, peran sosial dan kereampilan yang mengakibatkan kelahiran usaha, kelangsungan hidup dan tumbuhnya usaha mikro kecil menengah (Hertati.2015: Mathis,et,all, 2010). Kompetensi usaha mikro kecil menengah adalah atribut seperti, keyakinan, pengetahuan, kerampilan, kemampuan, kepribadian, keahlian dan kecenderungan perilaku yang diperlukan untuk sukses dan menopang usaha mikro kecil menengah ( Michael Stoica, et,all, 2013). Usaha mikro kecil menengah Gambo Muba adalah sebagai pengetahuan, keterampilan dan sikap terintegrasi komponen. Kompetensi Usaha mikro kecil menengah Gambo Muba yang juga disebut kemampuan serta pengetahuan dan keterampilan yang diperlukan untuk melakukan inovasi-inovasi baru didalam mengembangkan industry kreatif Gambo Muba.

Michael and Robert (2013) and Hertati (2015) ompetensi Usaha mikro kecil menengah Gambo Muba adalah kesatuan dari pengetahuan (knowledge), keterampilan (skill) dan kemampuan (ability) yang bersifat dinamis yang diperagakan oleh seorang Usaha mikro kecil menengah Gambo Muba sehingga 
terpancarkan dari perilakunya untuk mencapai kesuksesan dalam bisnisnya secara berkesinambungan. Ciri-ciri kreativitas kerajinan UMKM Gambo Muba adalah sebagai berikut (Nilmawati 2003) :

1. Kenali bisnis.

Terkait jenis bisnis yang akan dijalankan sangat perlu pemahaman mendalam tentang bisnis yang akan dikembangkan sehingga memberi nilai positif terhadap kemajuan bisnis (Hertati, 2016).

2. Mengetahui dasar manajemen bisnis

Kesuksesan dalam berbisnis ditandai dengan tercapainya tujuan bisnis dan proses pengembangan meningkat pesat (Hertati, 2020).

3. Memiliki sikap yang yang baik

Sikap dasar manajemen bisnis menjadi pondasi yang kuat bagi UMKM agar produk tetap diminati masyarakat sehingga dapat membangun bisnis didalam jangka panjang (Hertati, 2020).

4. Memiliki modal yang cukup

Manajemen keuangan merupakan cara untuk memperoleh uang sebagai mesin produksi serta proses penggunaan uang tersebut bisa disusun secara rinci. (Hertati, 2020)

\section{UMKM Kearipan Lokal Muba}

Keunggulan UMKM Gambo Muba adalah berbeda dengan UMKM lainya, dimana UMKM Gambo Muba dikerjakan dengan tangan tanpa dibantu mesin dan hubungan antar manusia, kompetensi didalam merakit usaha mikro kecil menengah yang berhubungan dengan kemampuan menjaga, membangun, mengembangkan, hubungan baik dengan orang, serta pihak yang berkepentingan dengan aktivitas masyarakat umum, seperti penyalur barang, pemasok bahan, pangsa pasar dan masyarakat umum UMKM Kearifan Lokal Muba dengan ciri-ciri sebagai berikut:

1. Mengatur keuangan secara efisien

Dalam mengelola keuangan, penting bagi pelaku UMKM untuk menentukan persentase di awal saat melakukan perencanaan bisnis dan anggaran, bisnis UMKM yang memiliki acuan untuk alokasi operasional kegiatan, target keuntungan yang ingin dicapai, cadangan kas hingga pengembangan bisnis. (MelHealy, 1983)

2. Mengatur waktu secara efisien

Manajemen waktu merupakan suatu guideline atau panduan yang terdiri dari perencanaan, pengendalian dan struktural cara menggunakan terhadap seberapa banyak waktu yang kita pakai dan gunakan untuk menyelesaikan suatu pekerjaan (Barney,2010).

3. Mengelola orang lain

Empati, kemampuan untuk memahami apa yang dipikirkan dan dirasakan orang lain, adalah dasar dari kemampuan untuk bekerja sama dengan baik (Hertati, etall, 2019)

4. Memuaskan pelanggan dengan menyediakan produk berkualitas

Pelanggan merasa puas maka pelanggan akan bertahan dengan produk UMKM Gambo Muba dalam waktu lama kemudian kepuasan pelanggan juga menjadi salah satu tolok ukur keberhasilan yang juga berdampak pada tingkat penjualan (Hertati, et,all, 2019.

\section{Peran Gambo Muba Didalam Meningkatkan Penjualan UMKM Kearipan Lokal Muba}

Penelitian Mitchelmore, et,all (2009) menyatakan bahwa usaha mikro kecil menengah saat ini dapat memberikan kontribusi pada beberapa aspek kehidupan masyarakat. Tidak hanya ditinjau dari sudut pandang ekonomi semata, tetapi juga dapat memberikan dampak positif kepada aspek lainnya seperti peningkatan citra dan identitas Produk asli Muba dan menumbuhkan inovasi dan kreativitas anak bangsa dan memiliki dampak sosial yang positif bagi suatu bangsa (Motakallem, 2014: Myers, 2000: Rameshwar, et,all, 2011: Rastgar \& Memarpour, 2012: Reniati,2013: Rivai,2017). Usaha mikro kecil menengah gambo Muba adalah kerajinan lebih bertumpuh pada kualitas sumber daya manusia 
sebagai kegiatan ekonomi yang benar-benar mencerminkan potensi dan produktivitas sumber daya lokal, memainkan peran penting dalam menciptakan nilai tambah melalui keberadaan produk atau jasa kreatif (Robert,1993: Rohana,2015: Safaria,2007: Syarudin \& Hertati: 2020: Wu,et,all,2013).

Penelitian Lestar \& Hertati (2020) menyatakan bahwa didalam menjalankan usaha, seorang perajin bukan hanya dituntut untuk dapat berinovasi dan memiliki kompetensi yang unggul, namun diperlukan jiwa yang kuat yang dapat mendorong keyakinan perajin akan keberhasilan usaha bisnis yang ditekuninya. Jiwa kuat tidak gampang menyerahl merupakan wujud dari kecerdasan emosi manusia (Thomas,et,all, 2002: Safkaur \& Herati, 2020: Santandreu, et,all, 2010). Kecerdasan berpikir yang dimiliki para pelaku UMKM di terapkan di dalam setiap proses kerja. Proses kerja yang berjalan dengan baik tidak luput dari kemampuan manajerial para UMKM dalam mengelola aktivitas usaha untuk menjadi perusahaan yang unggul, tentu harus didukung oleh kualitas sumber daya manusia yang memadai. Permasalahannya adalah, bagaimana menciptakan sumber daya manusia yang menghasilkan kinerja yang optimal sesuai dengan apa yang diharapkan oleh UMKM gambo Muba. Sumber daya manusia yang memiliki pengetahuan dan keterampilan diharapkan dapat meningkatkan kualitas proses kinerja maupun hasil kerjanya (Agelopoulos, 2017: Masoumeh Simbar, 2013). Berikut Ini adalah kerangka pikir penelitian

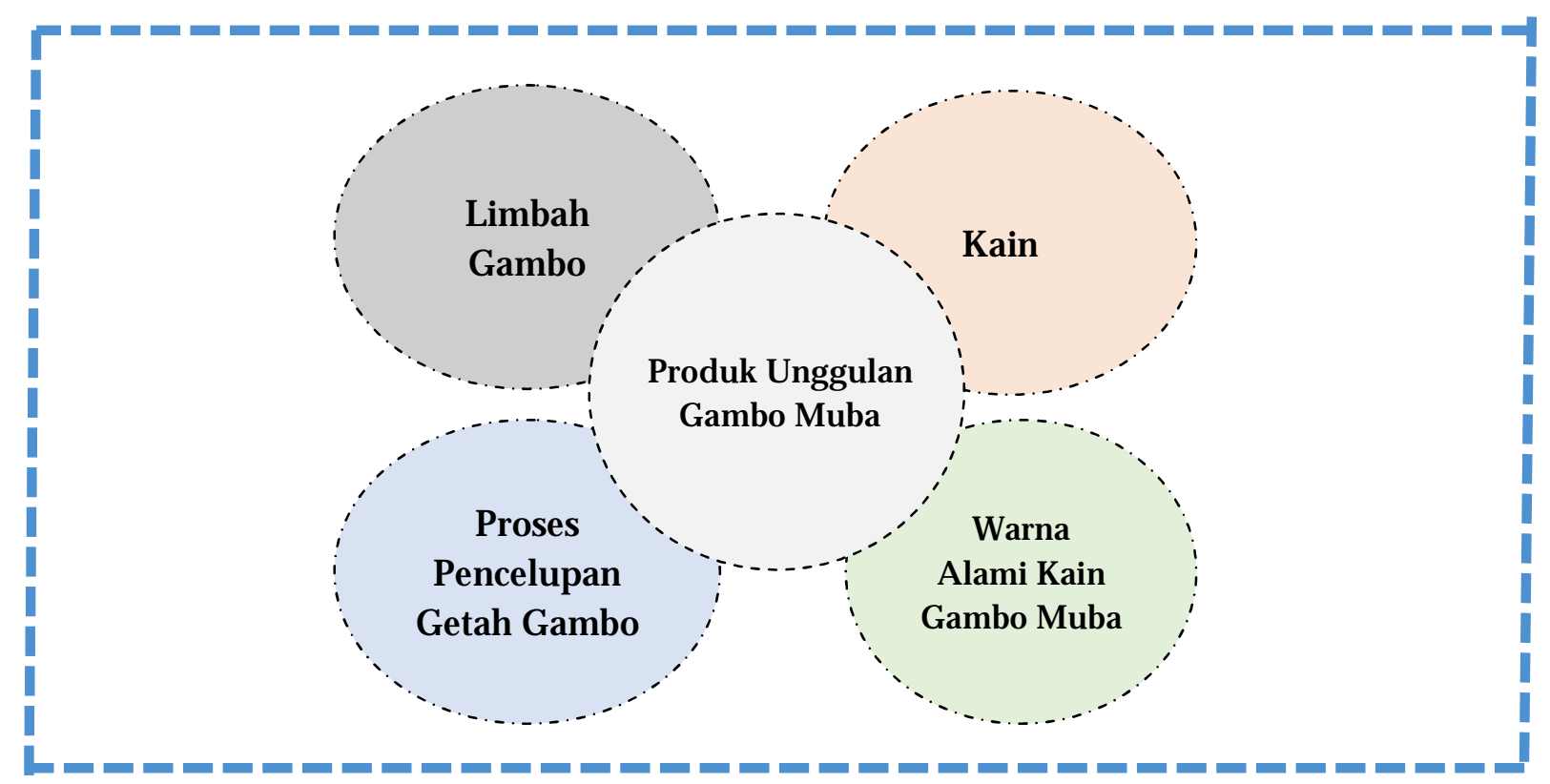

Figure.4 .1Framework Scheme, 2020

Hipotesis: bagaimana peran UMKM Gambo Muba didalam meningkatkan penjualan UMKM Kearifan Lokal Muba.

\section{Diskusi}

Rosli, \& Sidek (2013) menyatakan bahwa variasi dalam kinerja UMKM produk unggulan dengan kebutuhan masyarakat sangat erat kaitanya, temuan juga menginformasikan UMKM pembuat kebijakan bahwa inovasi produk merupakan faktor penting dalam kegiatan usaha mikro kecil menengah saat ini. Rohana \& Zarina (2015) menyatakan bahwa dengan adanya Inovasi yang sedang buming adalah salah satu kriteria penting yang digunakan untuk mengevaluasi kinerja aktivitas produk unggulan masyarakat local yang menerapkan cara kerja, teknologi dan produk baru sehingga akan diperoleh hasil kerja yang tinggi. Semakin kuat design inovasi yang baru yang dimiliki maka akan semakin tinggi 
peminat konsumen terhadap produk local yang unik diperlihatkan. Pendapat lain yang mendukung keterkaitan antara inovasi produk dengan kinerja UMKM dikemukakan oleh Regis,et,all (2003) yang menyatakan bahwa design inovasi merupakan salah satu kriteria penting yang digunakan untuk mengevaluasi peminat didalam mebeli produk lokal setempat (Andersen,et,all, 2006).

Robbins \& Judge ( 2007) menyatakan bahwa Design inovasi terus menerus akan menciptakan sintesis dari akumulasi pengetahuan, yang mengarah ke pertumbuhan produk-produk local baru sehingga perekonomian masyarakat dapat meningkat. Demikian juga dengan Regis (2012) menyatakan bahwa kegiatan inovasi produk unggulan yang unik yang berkelanjutan membuat UKM lebih kompetitif dan menghasilkan tingkat yang lebih tinggi dari hasil kinerja masyarakat local (Aral \& Dellarocas, 2011).

Adanya dampak inovasi terhadap kinerja pun dikemukakan Sánchez, (2011) dengan mengemukakan hasil penelitiannya bahwa inovasi memiliki dampak terhadap kinerja dimana dampak positif inovasi pada efisiensi dan kinerja perusahaan memerlukan klarifikasi pada dua poin. Poin pertama adalah bahwa investasi dalam inovasi dan teknologi harus diperlakukan sebagai masukan positif ke dalam efisiensi perusahaan bukan sebagai tokoh biaya yang menguras perusahaan (seperti yang sering dijelaskan di pendekatan klasik keuangan dan akuntansi). Poin kedua adalah bahwa investasi tersebut harus terkait dengan biaya produksi yang mencerminkan pemanfaatan yang benar dari sumber daya perusahaan (Aras,et,all, 2018).

Penelitian Man,,et,all (2002) dan Masood ,et,all (2013) mengembangkan dari usaha mikro kecil menengah perlu dicermati beberapa hal seiring perkembangan teknologi inovasi yang mengharuskan trend model terbaru saat ini sehingga usaha mikro kecil menengah rumahan seperti: perkembangan usaha harus diikuti dengan pengelolaan manajemen yang baik, perencanaan yang baik akan meminimalkan kegagalan, penguasaan ilmu pengetahuaan akan menunjang keberlanjutan usaha tersebut. Kemudian Penenlitian Masound \& Venny (2012), menyimpulkan bahwa mengelola sistem produksi yang efisien dan efektif, serta melakukan terobosan dan inovasi yang menjadikan pembeda dari pesaing merupakan langkah menuju keberhasilan dalam mengelola usaha usaha mikro kecil menengah. Selanjutnya Mathis, \& John (2012) menyatakan bahwa usaha mikro kecil menengah termasuk ekonomi produktif yang berdiri sendiri, yang dilakukan oleh orang perorangan atau badan usaha yang bukan merupakan anak perusahan atau bukan anak cabang yang dimiliki, dikuasai atau menjadi bagian, baik langsung maupun tidak langsung, dari usaha menengah atau usaha besar yang memenuhi kriteria usaha kecil (Michael and Robert,2013: Okpara,2007: Ozkaya,et,all, 2014: Ozkaya,et,all, 2011: Rahmah Islamil,et,all, 2010: Rivai, 2008).

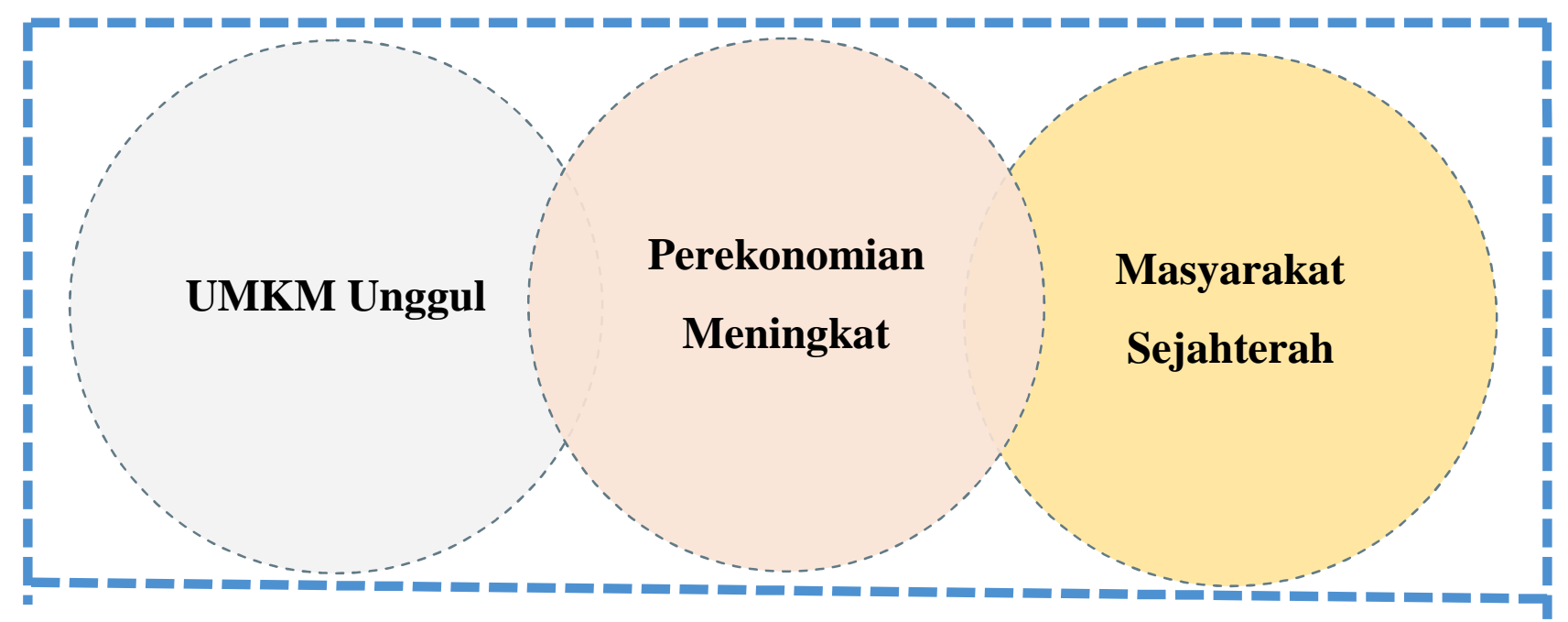

Gambar 5: UMKM Gambo Muba, 2020 


\section{Kesimpulan}

Secara umum para perajin usaha kerajinan skala mikro kecil menengah di kabupaten Musi Banyuasin telah memiliki tingkat kecerdasan yang baik dalam menjalankan usahanya. Para perajin usaha kerajinan juga memiliki kompetensi sumberdaya manusia yang cukup. Perajin usaha kerajinan cukup memiliki kemampuan dalam melakukan inovasi. Secara umum para perajin usaha kerajinan juga memiliki kinerja usaha yang baik sesuai dengan standar yang ditetapkan. Hal ini diketahui dari kemampuan menyelesaikan pekerjaan secara teliti sesuai dengan target kuantitas serta waktu yang diharapkan. Perajin juga dapat bekerja dengan menggunakan sumber daya yang efektif dan efisien. Memiliki tingkat kemandirian yang baik karena usaha jumputan Gambo Muba memanfaatkan sisa limbah alam yang tidak terpakai, yang ditandai dengan bekerja tanpa adanya pengawasan, memberikan bantuan dan rasa tanggung jawab terhadap keputusan yang diambil. Komitmen pengrajin juga berada dalam kategori baik, dalam hal ini pengrajin memiliki komitmen afektif yang tinggi untuk usaha mikro kecil menengah di Kabupaten Musi banyuasin-Indonesia mempunyai potensi yang besar untuk dikembangkan karena pasar yang luas, dekat dengan bahan baku yang ada dengan memanfaatkan limbah getah Gambir yang mudah didapat serta memanfaatkan sumber daya manusia ibu-ibu rumahan yang sedang terjadi masalah Corona sehingga mengharuskan berdiam dirumah menghindar dari keruman orang guna mengurangin penyebaran Covid-19 menyebar luas.

\section{Ucapan Terima Kasih}

Pengabdian Pada Masyarakat Lokal ini kerja sama dengan pemerintah Musi Banyuasin didalam memperoleh data. Kami juga berterima kasih kepada seluruh pelaku UMKM Gambo Muba yang telah bersedia diwawancara didalam merampung tulisan ini. Mereka telah memberikan dukungan dengan berbagi pengetahuan, pengalaman, dan wawasan terkait proses pembuatan jumputan Gambo Muba. Meskipun mereka mungkin tidak setuju dengan banyaknya wawancara didalam proses pembuatan jumputan Gambo Muba dengan semua interpretasi dan kesimpulan dari tulisan ini.

\section{Daftar Pustaka}

Agelopoulos.,K (2017) Does public sector efficiency matter? Revisiting the relation between fiscal size and economic growth in a world sample.Public choice. 137, (1), 245-278

Andersen, B. Henriksen.,B, Aarseth., W. (2006). Holistic performance management: an integrated framework", International Journal of Productivity and Performance Management, 55 (1).61-78.

Anshoff.,H I (1972) Societal strategy for the business firm. New York Graw Hill,

Aral.,S., dan Dellarocas., C (2011). Introduction to the Special Issue-Social Media and Business Transformation: A Framework for ResearchInformation System Research . 24 (1) 3-13

Aras, G., Tezcan, N., \& Kutlu, O. (2018). Multidimensional comprehensive corporate sustainability performance evaluation model: Evidence from an emerging market banking sector. Journal of Cleaner Production. Pp 1-26

Archak, N., Ghose, A., \& Ipeirotis, P. G. (2011). Deriving the Pricing Power of Product Features by Mining Consumer Reviews. Management Science, 57 (8), 1485-1509

Astuti, M., Ritonga, M., Irviani, R., Mukhlis, H., \& Chauhan, R. (2020). Developing Regional Autonomy: 
Lesson Learned from Norway. European Journal of Molecular \& Clinical Medicine, 7(02).

Atmasari, Y., Sanjaya, R., \& Fauziah, N. (2020). Hubungan tingkat pengetahuan tentang rokok dengan perilaku merokok pada remaja di SMKN Pagelaran Utara Pringsewu Lampung. Majalah Kesehatan Indonesia, 1(1), 15 - 20. doi:https://doi.org/10.47679/makein.011.42000004

Athanassopoulou, P., \& Johne, A. (2003). "Effective communication with lead customers in developing new banking products", International Journal of Bank Marketing, . 22 ( 2).100-125.

Barney,J.B. (2010). Gaining and Sustaining Competitive Advantage, Fourth Edition. Addison-. Wesley, Massachusetts

Best, Roger J.,2013, Market-Based Management (6 th Edition), strategies for growing customer value and profitability. NY.Pearson Higher Education

Borch, F.J. (1947), The Marketing Philosophy as a Way of Business Life, General Electric, New York, NY

Brentani, U. De. (1993). "The New Product Process in Financial Services: Strategy for Success", International Journal of Bank Marketing, . 11 Iss: 3 pp. 15 - 22

Broadbent, M., Brien, T., \& Brien, T. O. (1996). Firm Context and Patterns of IT Infrastructure Capability ( Best Paper Award ).CIS 1996 Proceedings. 13. Pp 174-194

Bryson, J. M., Ackermann, F., \& Eden, C. (2007). Putting the resource-based view of strategy and distinctive competencies to work in public organizations. Public Administration Review, 67(4), 702717

Bughin.,J (1996). Trade Unions and Firms' Product Market Power. The Journal of Industrial Economics, . 44 (3), pp. 289-307

Gartner, W.B., Carter, N.M., \& Hills, G.E. (2003). The language of opportunity. In C. Steyaert \& D. Hjorth (Eds.), New movements in entrepreneurship(pp. 103-124). London: Edward Elgar.

Hendrawati, Y., Ridwan, F., Kravchenko, O. D., Mukhlis, H., \& Irviani, R. The Notion of State Owned Plantation Enterprises. European Journal of Molecular \& Clinical Medicine, 7(02), 2020.

Hertati. L (2015). Competence of Human Resources, The Benefits of Information Technology on Value of Financial Reporting in Indonesia. Research Journal of Finance and Accounting 6, (8) 12-18

Hertati, L.(2015). Internal Control And Ethics Of Quality Management System Accounting Information And Implications On The Quality Of Accounting Information Management: Proposing A Research Framework. International Journal of Economics, Commerce and Management United Kingdom 3 (6) $902-913$

Hertati.L, Susanto.A. Zarkasyi.W, Suharman.H, Umar.H . (2019).Pengujian Empiris Bagaimana Kualitas Sistem Informasi Akuntansi Yang Dipengaruhi Oleh Etika Organisasi Berimplikasi Terhadap Kualitas Informasi Akuntansi (Survey pada Badan Usaha Milik Negara (Bumn) Di Sumatera Selatan Indonesia). Jurnal Ilmiah Akuntansi Rahmaniyah (JIAR) 3 (1) 88 - 107.

Hertati.L \& Safkaur.(2020). The Influence of Information Technology Covid-19 Plague Against Financial Statements and Business Practices IJTC Ilomata International Journal of Tax \& Accounting. 1 (3) $122-131$

Hertati, L. Widiyanti.M.Desfitrina. Syafarudin.A. (2020). The Effects Of Economic Crisis On Business Finance. International Journal of Economics and Financial Issues 10, (3) 236-244.

Hertati.L, Fery.I, Safkaur.O.2020. Pengaruh Komitmen Organisasi Terhadap Sistem Informasi Keuangan. Akuntabilitas: Jurnal Ilmu Akuntansi Volume 13 (1),125-136

Lestari.R \& Hertati.L.(2020). Bagaimana Pengaruh Strategi Bisnis, Kekuatan Produk Terhadap Kualitas 
Sistem Informasi Akuntansi Manajemen: Studi Kasus Pada Usaha Kecil Dan Menengah Di Indonesia. KAJIAN AKUNTANSI. 21(1)1-12

Man, T.W.Y., T. Lau and K.F. Chan. (2002). "The Competitiveness of Small and Medium Enterprises: A Conceptualization with Focus on Entrepreneurial Competencies," Journal of Business Venturing 17, no. 2: 123-42.

Masood Ul Hassan, Shadia Shaukat, Muhammad Saqib Nawaz, Saman Naz, (2013) ,Effects of Innovation Types on Firm Performance: anEmpirical Study on Pakistan's Manufacturing Sector, Pakistan Journal of Commerce and Social Sciences . 7 (2), 243-262.

Masoumeh Simbar.(2013). The Peer Education Approach in Adolecents-Narrative Review Article. Iranian J Publ Health, 42, (11) PP.1200- 1206.

Masound D and Venny (2012), Evaluation the Characteristics of Entrepreneurial Internet Service Administrators, Shiraz Journal of System Management Special Issue 20(14), 1-12.

Mathis Robert L, Jachson John H, (2010), Manajemen Sumber Daya Manusia, Edisi Kesepuluh, Penerbit Salemba Empat, Jakarta.

Mathis, Robert L dan John H.Jackson.(2002). Manajemen Sumber Daya Manusia. Jakarta : Edisi Pertama. Salemba Empat.

Mei Yane Chung W (2012). Family ownership and firm performance: Influence of family management, family control,and firm size. Asia Pacific Journal of Management, 28(4): 833-851.

MelHealy (1983), Innovative Ireland-technological, industrial and societal challenges, TechnovationVolume 2, Pages 45-53.

Michael Stoica and Robert J Boncella, (2013). The relationship between innovation, knowledge, and performance in family and non-family firms: an analysis of SMEs, Journal of Innovation and Entrepreneurship 29, 1141- 1154.

Michael Stoica, Robert J Boncella, (2013).The relationship between innovation, knowledge, and performance in family and non-family firms: an analysis of SMEs"Journal of Innovation and Entrepreneurship Volume 45, Pages 26-50.

Mitchelmore, Siwan dan Jennifer Rowley. (2009). Entrepreneurial Competencies: A Literature Review and Development Agenda. International Journal of Entrepreneurial Behaviour and Research, 16 (2): 92-111.

Motakallem, A. (2014). Role of Personality Traits and Spiritual Intelligence in redicting Work Performance of School Principals. International Journal of Basic Sciences \& Applied Research., 3, 1418.

Myers, I. B. (2000). Guide to the Development and Use of the Myers - Briggs Type Indicator (3rd ed.). CPP. Inc.

Nilmawati.(2003).Mencapai kesuksesan organisasi melalui pemberdayaan. Jurnal Ekobis. Vol.4 No.2.

Okpara, Friday.(2007) “The Value Of Creativity And Innovation In Entrepreneurship".Journal Of Asia Entrepreneurship And Sustainability:. Vol 3, Issue2:9:07.

Ozkaya, C. Droge, G. Tomas, M. Hult, R. Calantone, E. Ozkaya,(2014), Market orientation, knowledge competence, and innovationInternational Journal of Research in Marketing, Journal of Innovation \& Knowledge, 32 (3) (2015), pp. 309-318.

Putra, P., Kembauw, E., Sebayang, A., \& Mukhlis, H. (2020). State Owned Enterprise for the Creation of Prosperity for All Indonesian. Journal of Critical Reviews, 7(8), 2032-2036. 
Qureshi, JA., Hayat, Khansa., Ali Mehwish., Sarwat, Nosheen., (2011), Impact of Job Satisfaction and Organizational Commitment on Employee Performance, Evidence from Pakistan, Journal of Contemporary Research in Business, Vol 3, No 4, Aug 2011.

Rahmah Islamil Syahida Z. Abidin. (2010). "Impact of workers' competence on their performance in the Malaysian private service sector".BEH - Business and Economic Horizons. Volume 2, Issue 2, July 2010, pp. 25-36. ISSN: 1804-1205.

Rameshwar Dubey, Sadia Samar Ali. (2011). Study on Effect of Functional Competency on Performance of Indian Manufacturing Sector. 1 Int. j. eng. bus. manag., 2011, Vol. 3, No. 3, 1-15.

Rastgar, M., \& Memarpour, S. (2012). The relationship between emotional intelligence and self-efficacy among Iranian EFL teachers. System, vol 37, pg 700-707.

Regis Cabral, E.Titus,J.Grácio, (2003) Cutting performance of time-modulated chemical vapour deposited diamond coated tool inserts during machining graphite, Diamond and Related Materials 1(5), 1753-1758.

Reniati. (2013). Kreativitas Organisasi \& Inovasi Bisnis, Implementasi pada IKM Berbasis Kreativitas dan Budaya Menuju Keunggulan Bersaing Global. Bandung: Alfabeta.

Rivai, Veithzal dan Deddy Mulyadi. (2012). Kepemimpinan dan Perilaku OrganisasiEdisi Ketiga. Jakarta : PT. Rajagrafindo Persada.

Robbins, S.P. and Judge, T.A. (2007). Organizational Behavior. 12th edition. New Jersey: Pearson Prentice-Hall.

Robert A. Emmons (1993). Is Spirituality an Intelligence? Motivation, Cognition, and the Psychology of Ultimate Concern, The International Journal for the Psychology of Religion, 10:1, 3-26

Rohana Ngah, Zarina Salleh (2015), Emotional Intelligence and Entrepreneurs' innovativeness towards Entrepreneurial Success: A Preliminary Study American Journal of Economics 5(2): 285-290.

Rohana N, \& Zarina S. (2015). “Emotional Intelligence and Entrepreneurs' innovativeness towards Entrepreneurial Success: A Preliminary Study". American Journal of Economics 2015, 5(2): 285-290.

Rosli, M.M. \& Sidek, S. (2013). The Impact of Innovation on the Performance of Small and Medium Manufacturing Enterprises: Evidence from Malaysia. Journal of Innovation Management in Small \& Medium Enterprise, 2013.

Rusmardiana, A., Supriadi, F., Irviani, R., Mukhlis, H., \& Chauhan, R. (2020). The Role of Sales Promotion Girl on Purchase Intention. European Journal of Molecular \& Clinical Medicine, 7(02), 2020.

Safaria, T. (2007). Spritual intellegence metode pengembangan kecerdasan spiritual anak, Yogjakarta: Graha Ilmu.

Sánchez, J. (2011). University Training for Entrepreneurial Competencies: Its Impact on. International Entrepreneurship and Management Journal, 7(2), 239-254.

Santandreu Mascarell, C., Canós-Darós, L., \& Pons-Morera, C. (2010). Competencies and skills for future Industrial Engineers defined in Spanish degrees. Journal of Industrial Engineering and Management, 4(1), 13-30.

Syarudin.A \& Hertati.L.(2020). Penerapan Human Capital, Kualitas Pelayanan Pada Sistem Informasi Manajemen. 5 (1 ) 31-45

Safkaur.O, \& Herati.L.(2020). Perubahan Struktur Modal Menyebabkan Perubahan Kinerja Keuangan. Jurnal Ekonomi Dan Perbankan 9(2) 94-105

Thomas W.Y. Man Theresa LauK. FChan, (2002) The competitiveness of small and medium enterprises: 
A conceptualization with focus on entrepreneurial competencies, Journal of Business Venturing.17 (2) $123-142$

Teten Masduki.(2020). Terpukul Corona, Ini 5 Keluhan Para Pelaku UMKM. https://money.kompas. com/read/2020/03/27/190000026/terpukul-corona-ini-5-keluhan-para-pelaku-umkm Wu, M. Y., \& Lee, Y. R. (2011). The effects of internal marketing, job satisfaction and service attitude on job performance among high-tech firm. African Journal of Business Management.

Wahyuni, R., Rohani, S., Oktavianti, R., \& Mukhlis, H. (2019). Hubungan Kepuasan Pengguna Kartu BPJS Terhadap Mutu Pelayanan di Rumah Sakit Daerah Kotabumi Lampung Utara. Wellness And Healthy Magazine, 1(2), 201-2017. Retrieved from https:/wellness.journalpress.id/wellness/article/view $/ v 1 \mathrm{i} 225 \mathrm{wh}$

Wu, T., E.M. Daniel, M. Hinton, dan P. Quintas. (2013). Isomorphic Mechanisms in Manufacturing Supply Chains: A Comparison of Indegenous Chinese Firms and Foreign-Owned MNCs. Supply Chain Management: An International Journal 18(2): 161-177.

Yuliaty, F., Purnama, Y., Akbar, F. M., Mukhlis, H., \& Irviani, R. (2020). Behavioristic Psychology of the Modern Constitution. Journal of Critical Reviews, 7(8), 2019-2023. 